\title{
Chemical Risk Factors of Primary Liver Cancer: A Short Comment [Letter]
}

\section{Laraib Ghanghro (D)}

Dow Medical College, Dow University of Health Sciences, Karachi, Pakistan
Correspondence: Laraib Ghanghro Dow Medical College, Dow University of Health Sciences, Karachi, Pakistan Email lareb.manan19@dmc.duhs.edu.pk

\section{Dear editor}

I have read with interest the article "Chemical Risk Factors of Primary Liver Cancer: An Update". I I appreciate the authors for this brilliant work.

The article has discussed the International Agency for Research on Cancer (IARC) identified chemicals related to medications, lifestyle and occupational exposure, which can potentially cause hepatocellular carcinoma (HCC). I suggest adding a few more such chemicals related to occupational exposure.

4-Aminobiphenyl (4-ABP) is classified as Group 1 carcinogen in humans. It was formerly used in the rubber and dye industry, now used as carcinogen in mutagenicity study and cancer research. Occupational exposure to 4-ABP can occur via 4-ABP contaminated products or benzidine and benzidine-based dyes which yield 4-ABP on metabolism. Its metabolism results in a mutagen, $\mathrm{N}$-hydroxyl ABP formation. It can form DNA adducts. Its ingestion in rats results in bladder cancer, angiosarcoma and $\mathrm{HCC}^{2}$ It has been associated with bladder cancer in workers exposed to it. Increased 4-ABP DNA levels were observed in HCC patients than controls. ${ }^{3}$

4,4'-Methylene bis (2-chlorobenzenamine) (MOCA) is also an IARC Group 1 agent. It is used for polyurethane prepolymers in the manufacture of castable urethane rubber products and as a model compound to study carcinogens. Workers can be exposed during its production and use in the polyurethane industry mainly via dermal contact. It interacts with DNA and haemoglobin to form adducts. In vivo studies indicate risk of lung and mammary gland adenocarcinoma, and HCC. Bladder cancer risk has been identified in workers exposed to it. ${ }^{2}$

Ortho-Toluidine (o-toluidine) is used for production of herbicides, such as metolachlor and acetochlor, dyes and pigments, rubber, pharmaceuticals and other chemicals. In the laboratory it is used for glucose analysis and tissue staining. Occupational exposure can occur while manufacturing these products. Laboratory staff may be exposed while staining tissues. Epidemiological studies show significant association between its exposure and human bladder cancer. ${ }^{2}$ Oral administration in rats causes increased risk of HCC. There is sufficient evidence for its carcinogenicity in humans and animals (Group 1). ${ }^{2}$

Benzidine and dyes metabolized to it are Group 1 carcinogens. Benzidine is used in dye production to color textiles, leather, and paper products and in the petroleum, rubber, plastics, wood, soap, fur, and hair-dye industries. ${ }^{2}$ Workers can be exposed during its production or use of products containing it. Although no evidence of human cancer due to its exposure, it has been shown to increase HCC in rats. ${ }^{4}$ 
Mentioning these compounds would allow further research to find association between them and human cancer and further awareness for people at risk.

\section{Disclosure}

The author reports no conflicts of interest in this communication.

\section{References}

1. Barsouk A, Thandra KC, Saginala K, Rawla P, Barsouk A. Chemical risk factors of primary liver cancer: an update. Hepat Med. 2021;12:179-188. doi:10.2147/HMER.S278070
2. International Agency for Research on Cancer (IARC). IARC Monogr. 100F. Lyon, France: Chemical Agents and Related Occupations; 2012.

3. Wang LY, Chen CJ, Zhang YJ, et al. 4-Aminobiphenyl DNA damage in liver tissue of hepatocellular carcinoma patients and controls. $\mathrm{Am}$ J Epidemiol. 1998;147:315-323. doi:10.1093/oxfordjournals.aje.a009452

4. National Toxicology Program. 13-week subchronic toxicity studies of direct blue 6, direct black 38, and direct brown 95 dyes. Natl Cancer Inst Carcinog Tech Rep Ser. 1978;108:1-117.

Dove Medical Press encourages responsible, free and frank academic debate. The content of the Hepatic Medicine: Evidence and Research 'letters to the editor' section does not necessarily represent the views of Dove Medical Press, its officers, agents, employees, related entities or the Hepatic Medicine: Evidence and Research editors. While all reasonable steps have been taken to confirm the content of each letter, Dove Medical Press accepts no liability in respect of the content of any letter, nor is it responsible for the content and accuracy of any letter to the editor.

Hepatic Medicine: Evidence and Research

Dovepress

\section{Publish your work in this journal}

Hepatic Medicine: Evidence and Research is an international, peerreviewed, open access journal covering all aspects of adult and pediatric hepatology in the clinic and laboratory including the following topics: Pathology, pathophysiology of hepatic disease; Investigation and treatment of hepatic disease; Pharmacology of drugs used for the treatment of hepatic disease. Issues of patient safety and quality of care will also be considered. The manuscript management system is completely online and includes a very quick and fair peer-review system, which is all easy to use. Visit http://www.dovepress.com/ testimonials.php to read real quotes from published authors. 